\title{
Learning Styles and Asynchronous Learning: Comparing the LASSI Model to Class Performance
}

Kenneth D. Loomis, Ph.D

Department of Communication and Journalism

Hibbard Hall 157

University of Wisconsin - Eau Claire

Eau Claire, WI 54701

Phone: 715-836-2528

E-mail: loomiskd@uwec.edu

\begin{abstract}
This study investigated the relationship between students' individual study and learning styles with their performances in an online Research Methods class. At the beginning of the semester the Learning and Study Strategies Inventory (LASSI) measured each student's study and learning styles on ten scales.
\end{abstract}

The students' LASSI scores were later correlated to their total class points, and grades on exams, projects, and assignments. Five of the LASSI scales had significant correlations with at least one aspect of the course assessment. The strongest correlation was found between time management skills and the final grade. The ability to effectively use study aids was significant in the students' performance on the final grade, the final exam and all activities outside exams (journal reports and chapter assignments).

KEY WORDS

Distance learning, Drop out rates, Study strategies

\section{BACKGROUND}

The use of personal computers in teaching ranges from entire courses conducted asynchronously (students participating in classroom "discussions," completing assignments and taking exams at different times and places on their computers) to courses where the computer content is only used as a supplement to material delivered in the traditional classroom lecture form. Universities, colleges and trade schools are rapidly developing course material that is delivered to students in on-campus computer labs or on the Internet at any location via modem or cable.

Most of the research on these asynchronous learning networks (ALNs) has attempted to identify how much students learn from ALN courses compared to traditional classroom contexts. Perhaps one of the broadest efforts at investigating asynchronous learning was reported by Arvan, Ory, Bullock, Burnaska and Hanson [1]. In that study, the University of Illinois at UrbanaChampaign's SCALE Efficiency Projects utilized computer-based instruction in seven different subject areas to make preliminary time and cost and student performance analyses. The authors found that student performance was comparable to the traditional classroom teaching environment with potential cost savings through time. 
Bond [2] compared student performance in a psychology class delivered via CD-ROM with another group that previously had taken the same class in the traditional manner. The CD program relied on audio lecture tracks mixed with numerous visual components to deliver the material. Bond compared the performance of the two groups of students (total $n=155$ ) on three multiple-choice tests. No real difference was found in the performance of students who took the course on CD in 1997 from those who completed the coursework in the traditional way during 1995.

Schutte [ $\underline{3}$ ] randomly divided a Social Statistics class of thirty-three students into two sections; one section took the course in the traditional classroom setting, the other section took the course on the Internet. The traditional section met in person fourteen times while the internet section met only twice after the first two weeks. The internet section scored significantly higher (an average of $20 \%$ ) than the traditional section on the two course exams.

Sherman [4] incorporated asynchronous learning components into an advanced Social Psychology course of ten students. The students reacted positively to the ALN components because their work was shared with others, and they likely experienced active (as opposed to passive) learning processes. However, on the course evaluation some of Sherman's students expressed dissatisfaction with the amount of time spent on learning and mastering the technical aspects of accessing Web based information. Wegner, Holloway and Garton [5] compared students' perceptions of their experiences in a course taught to one group on-line $(n=14)$, and to another group in the traditional classroom model $(n=17)$. Students were allowed to self-select into either section. The groups primarily consisted of part-time Masters degree students working on their principal certifications. The researchers found no significant difference in student performance on the final exam. However, the on-line students tended to express more positive feelings about the course.

With use of a post-course questionnaire, Hiltz [ 6 ] analyzed student satisfaction with the technical aspects of accessing and processing course material delivered on an ALN, and found--over a two year period--student satisfaction and course performance were comparable to the traditional classroom courses $(n=529)$. Ory, Bullock and Burnaska [7] discovered that gender played no significant role in ALN students' performance and satisfaction. With the use of post-course questionnaires, continuous monitoring of virtual class discussions and group interviews, the researchers observed females tended to use their computers more to communicate with the instructor and other students, while males more often accessed the World Wide Web. This study involved 2,151 students in twenty-three courses over two semesters.

\section{THE STUDY}

\section{The LASSI Measurement}

Little, if any, research to this point has been conducted on student learning styles in relation to asynchronous learning networks. We know individuals process information in varied ways. This study was designed to ascertain if students' learning styles influenced their performance in a Research Methods class taught asynchronously on Lotus Notes Learning Space software. In order to understand each student's learning style, every student in the class was administered the Learning and Study Strategies Inventory (LASSI) at the beginning of the semester. 
The LASSI [ $\underline{8}$ ] was designed in 1987, after nine years of development at the University of Texas at Austin, as a means to measure students' study and learning strategies and methods. The tool consists of ten scales, each measuring a different learning component. The ten scales are:

1. Attitude - the student's interest and motivation to succeed in college; and willingness to perform the tasks necessary for academic success (Alpha .72).

2. Motivation - the degree to which the student accepts the responsibility for performing those tasks by utilizing self-discipline and hard work (Alpha .81).

3. Time Management - the extent to which the student creates and uses schedules to manage effectively his or her responsibilities (Alpha .86).

4. Anxiety - the degree of anxiety the student feels when approaching academic tasks (Alpha .81).

5. Concentration - the ability of the student to focus his or her attention, and avoid distractions, while working on school-related tasks like studying (Alpha .84).

6. Information Processing - the ability to process ideas by mentally elaborating on them and organizing them in meaningful ways (Alpha .83).

7. Selecting Main Ideas - the magnitude of the student's ability to ferret out the important information in a learning situation (Alpha .74).

8. Study Aids - the student's ability to use or develop study aids that help the learning process (Alpha .68).

9. Self Testing - the student's awareness of the importance of self-testing and reviewing when learning material; and use of those practices (Alpha .75).

10. Test Strategies - the measurement of the student's ability to prepare effectively for an exam and to reason through a question when answering it (Alpha .83).

\section{METHOD}

During the 1999 Spring semester the university's Communication and Journalism Department offered an online section of the department's Research Methods class, which would be taught asynchronously with Lotus Notes Learning Space. The Learning Space software contains four main folders within which the course materials are presented: 1) Schedule holds the course syllabus, a due date calendar of assignments, readings and exams; 2) Courseroom contains lecture notes, directions on where to go for further readings, a classroom discussion bulletin board and other content oriented material such as directions on how to complete assignments and projects; 3) Media Center has the recorded audio and video components of the course; and 4) Profiles contains demographic and personal interest information of each student.

The course was designed to present the identical information provided in the traditional classroom sections of Research Methods. Each chapter, or section, of the course consisted of reading assignments posted in the Schedule folder, written lecture notes provided in the Courseroom folder, and a recorded audio lecture by the instructor in the Media Center. Each audio lecture was ten to twenty minutes in length. Typically, students would listen to the audio lecture while reviewing the provided written lecture notes. When graded assignments were given, the audio lecture would explain the assignment. A written description of the assignment-similar to something that would be handed out in class--was available in the Courseroom folder. When students had questions, they would contact the professor via the bulletin board in the Courseroom, by e-mail, by telephone or by visiting in person during the professor's office hours.

The first three class sessions were held in a campus computer lab to orient the students to the software and to course procedures. The midterm and final exams were administered in the traditional in-person classroom mode, as were several class sessions reserved for the students to 
present their final projects. All course lectures, assignments and discussions took place on line. For the course's final project the class was divided into six groups. Each group was given the assignment of designing and administering a small pilot study for one of several research questions provided by the instructor.

During the third in-person class session at the beginning of the semester the students were administered the LASSI. During the final class session of the semester, before the final exam was handed out, the students completed a short questionnaire about their perceptions of the course-what they liked and did not like, what went well and what did not go well. One student volunteered to collect these questionnaires and keep them until the week after grades were posted and to then return them to the instructor. After the semester was finished, and final grades posted, the instructor tabulated the results of the LASSI and the final in-class questionnaire.

Twenty-eight students began the semester in the class, twelve males and sixteen females. All were majors in one of the Communication and Journalism sequences. Eight students were Seniors, fifteen were Juniors, four were Sophomores, and one was a Freshman. Five students (four males and one female) dropped the course before, or immediately after, the midterm exam.

\section{RESULTS}

The students' answers on each of the LASSI scales were correlated with their performance on exams, the final class group project, four chapter assignments, and two journal article reports. The relationship between these variables is shown in Table 1. Significant associations were evident between student performance and five of the LASSI Scales: Attitude, Time Management, Concentration, Selecting Main Ideas, and Study Aids.

As indicated in Table 1, Attitude was a predictor for whether a student dropped the class before the end of the semester $(\mathrm{F}=2.857, \mathrm{p}=.029)$. Because the Attitude scale measures students' perceptions of how valuable and relevant college is to their futures, it is conceivable those who scored lower on this scale had less patience with learning and mastering a new learning tool because they were unable to connect the learning experience to their lives after college.

As one might anticipate, Time Management was a very strong predictor of one's overall performance in this class. Its correlation to Total Class Points was the strongest of all $(\mathrm{F}=9.443$, $\mathrm{p}=.005)$. Students who reported a weakness in managing their schedules received a lower final grade than those who reported good time management skills on the LASSI. It is perhaps self evident that the more structured daily class schedule of the traditional classroom, where students know they must physically attend each class on given days and times, supports those students who do not possess the skills of designing their own daily plans. In this class, as with most asynchronous learning networks, exams and assignment due dates were clearly established. However, the supposed benefit of ALNs is that students have the freedom to learn the material on their own time and are not limited by regularly having to be at a certain place at a given hour to access the material. The drawback, of course, is that if not given rigid attendance requirements some students do not have the skills to discipline themselves to adequately learn and study in a timely manner. The dilemma apparently was present for some of the students in this class. 


\begin{tabular}{|c|c|c|c|c|c|c|c|c|}
\hline & $\begin{array}{l}\text { Droppea } \\
\text { Class } \\
\text { F }\end{array}$ & $d f$ & $\begin{array}{l}\text { Journa } \\
\text { Report } \\
\text { F }\end{array}$ & & $\begin{array}{l}\text { Chapte } \\
\text { Assmts } \\
\text { F }\end{array}$ & $\begin{array}{l}\text { er } \\
\text { s. } \\
d f .\end{array}$ & $\begin{array}{l}\text { Final } \\
\text { Projec } \\
\text { F }\end{array}$ & $d f$ \\
\hline $\begin{array}{l}\text { Attitude } \\
51^{\text {st }} \text { percentile }\end{array}$ & $\underline{2.857}^{*}$ & 12 & 1.107 & 10 & 2.404 & 10 & .258 & 10 \\
\hline $\begin{array}{l}\text { Motivation } \\
38^{\text {th }} \text { percentile }\end{array}$ & .832 & 14 & .408 & 13 & 1.2841 & 13 & .656 & 13 \\
\hline $\begin{array}{l}\text { Time Mgmt. } \\
48^{\text {th }} \text { percentile }\end{array}$ & .616 & 16 & 1.612 & 15 & .702 & 15 & .360 & 15 \\
\hline $\begin{array}{l}\text { Anxiety } \\
50^{\text {th }} \text { percentile }\end{array}$ & .560 & 15 & 1.791 & 15 & .614 & 15 & 1.791 & 15 \\
\hline $\begin{array}{l}\text { Concentration } \\
51^{\text {st }} \text { percentile }\end{array}$ & 1.791 & 14 & 1.791 & 12 & 1.069 & 12 & 1.791 & 12 \\
\hline $\begin{array}{l}\text { Inf. Process. } \\
46^{\text {th }} \text { percentile }\end{array}$ & .992 & 15 & 1.791 & 15 & 1.791 & 15 & .946 & 15 \\
\hline $\begin{array}{l}\text { Sel. Main Ideas } \\
65^{\text {th }} \text { percentile }\end{array}$ & $\underline{3.601}^{* *}$ & * 9 & 1.791 & 7 & .314 & 7 & 1.033 & 7 \\
\hline $\begin{array}{l}\text { Study Aids } \\
\quad 46^{\text {th }} \text { percentile }\end{array}$ & 1.791 & 16 & 1.791 & 13 & 2.487 & 13 & 1.791 & 13 \\
\hline $\begin{array}{l}\text { Self Testing } \\
34^{\text {th }} \text { percentile }\end{array}$ & .484 & 13 & 1.0901 & 13 & 1.791 & 13 & .491 & 13 \\
\hline $\begin{array}{l}\text { Test Strategies } \\
51^{\text {st }} \text { percentile }\end{array}$ & 1.317 & 12 & 1.417 & 10 & .392 & 10 & .438 & 10 \\
\hline
\end{tabular}




\begin{tabular}{|c|c|c|c|c|c|c|c|c|}
\hline & \multicolumn{2}{|c|}{$\begin{array}{l}\text { Total Non- } \\
\text { Exam Points }\end{array}$} & \multicolumn{2}{|c|}{$\begin{array}{l}\text { Midterm } \\
\text { Exam }\end{array}$} & \multicolumn{2}{|l|}{$\begin{array}{l}\text { Final } \\
\text { Exam }\end{array}$} & \multicolumn{2}{|c|}{$\begin{array}{l}\text { Total Class } \\
\text { Points }\end{array}$} \\
\hline & $F$ & $d f$ & $F$ & $d f$ & $F$ & $d f$ & $F$ & $d f$ \\
\hline $\begin{array}{l}\text { Attitude } \\
51^{\text {st }} \text { percentile }\end{array}$ & .411 & 10 & 1.832 & 11 & .837 & 11 & .880 & 11 \\
\hline $\begin{array}{l}\text { Motivation } \\
38^{\text {th }} \text { percentile }\end{array}$ & .693 & 13 & 1.658 & 14 & 1.581 & 14 & 1.189 & 14 \\
\hline $\begin{array}{l}\text { Time Mgmt. } \\
48^{\text {th }} \text { percentile }\end{array}$ & .822 & 15 & .922 & 16 & 2.458 & 16 & $\underline{9.443}^{*}$ & *16 \\
\hline $\begin{array}{l}\text { Anxiety } \\
50^{\text {th }} \text { percentile }\end{array}$ & .706 & 15 & 1.791 & 15 & 1.791 & 15 & .584 & 15 \\
\hline $\begin{array}{l}\text { Concentration } \\
51^{\text {st }} \text { percentile }\end{array}$ & $\underline{3.112}^{*}$ & 12 & 1.050 & 12 & .634 & 12 & 1.791 & 12 \\
\hline $\begin{array}{l}\text { Inf. Process. } \\
46^{\text {th }} \text { percentile }\end{array}$ & .942 & 15 & 1.098 & 15 & .750 & 15 & 1.791 & 15 \\
\hline $\begin{array}{l}\text { Sel. Main Ideas } \\
65^{\text {th }} \text { percentile }\end{array}$ & .714 & 7 & .706 & 8 & .728 & 8 & .497 & 8 \\
\hline $\begin{array}{l}\text { Study Aids } \\
\quad 46^{\text {th }} \text { percentile }\end{array}$ & $\underline{4.392}^{*}$ & 13 & 1.791 & 14 & $\underline{3.839}^{*}$ & 14 & $\underline{4.120}^{*}$ & 14 \\
\hline $\begin{array}{l}\text { Self Testing } \\
34^{\text {th }} \text { percentile }\end{array}$ & .903 & 13 & .807 & 13 & 1.791 & 13 & .906 & 13 \\
\hline $\begin{array}{l}\text { Test Strategies } \\
51^{\text {st }} \text { percentile }\end{array}$ & .580 & 10 & 1.657 & 10 & .633 & 10 & .576 & 10 \\
\hline
\end{tabular}

* Statistically significant at alpha $=.05$

$* *$ Statistically significant at alpha $=.01$

Table 1. Relationship Between Student Performance and LASSI Scales One Way ANOVA.

The LASSI Concentration scale is designed to measure students' ability to focus attention, and maintain that attention, on academic tasks. Students who do not report good concentration skills are likely to be easily distracted by competing thoughts, or by other events, while studying. Perhaps one of the more intriguing results was the relationship between the Concentration scale and the Total Non-Exam points. While Table 1 does not show strong correlations between Concentration and the individual non-exam elements of the course (journal reports, chapter assignments, and the final project), the combination of those three elements (Total Non-Exam Points) does show a connection $(\mathrm{F}=3.112, \mathrm{p}=.041)$. Perhaps students who did not report strong concentration skills on the LASSI had marginally lower performances on each non-exam assignment. The difference shows up as significant when adding together the performances of all those assignments. Again, because of the asynchronous nature of this course, it is likely some students did not focus their undivided attention on the assignments as they might have in a more 
controlled classroom environment. It is possible the distractions of computer labs or dormitory rooms compromised some students' abilities to focus on the material.

The Selecting Main Ideas scale measures a student's ability to pick out the important and relevant information of a learning situation. The students who dropped the class tended to score lower on this scale than did the students who remained $(\mathrm{F}=3.601, \mathrm{p}=.010)$. One can imagine that, when dealing with a potentially confusing new learning environment such as internet based computer software, some students might get lost in the details of accessing all of the course materials as well as determining what was important once they did access them. Without regular in-class cues from the instructor about important information, students who did not possess this type of study skill might have felt frustration with the course.

The LASSI scale with the greatest number of performance correlations was Study Aids. The Study Aids scale was a predictor for Total Non-Exam Points $(\mathrm{F}=4.392, \mathrm{p}=.016)$, Final Exam points $(\mathrm{F}=3.839, \mathrm{p}=.031)$, and Total Class Points $(\mathrm{F}=4.120, \mathrm{p}=.025)$. The LASSI Study Aids scale measures one's ability to create and/or utilize existing study aids in learning a subject. Study aids in the traditional context may be such things as emboldened or colored text, underlined text, summary statements, charts and graphs, etc. Students in this class who did not report good study aids skills on the LASSI did not do as well in the course. Students must be proficient in flipping back and forth between several different folders on the course's web page, and then relating all this material to assigned readings. When a student has a question during this process, he or she must feel comfortable in joining a bulletin board discussion group or e-mailing the professor with a question. Therefore an individual who does not recognize the importance of simple emboldened textbook text is likely to have difficulty utilizing and understanding the multilayered design of an online internet course.

\section{DISCUSSION}

The study skills each student brought to this class was an important determinant of his or her success in the course. One of the benefits of the traditional classroom setting is that the more rigid structure (regular class meetings and frequent teacher reinforcement of important information) helps support some students with mediocre learning and studying skills. In the traditional classroom much of the pressure in the learning environment is on the teacher and the system itself. Oftentimes instructors in the traditional classroom can detect when an individual does not understand or is unprepared for class, and can respond accordingly. Students in an asynchronous learning network do not have the benefit of such support. All of the course information is presented and available; but it is almost entirely up to the student to access and process it.

For many students with good time management and study aids skills the flexibility of this ALN actually improved the learning experience as evidenced by these written student evaluation comments:

The amount of learning increased because I was able to go back and listen to the lectures over and over again, whereas in a traditional classroom, the lectures are perishable. My motivation increased because I knew that I had to be disciplined and motivated to get a good grade in the course. 
I usually stay on top of my schoolwork and was no different with this course. I made sure to keep up with assignments week by week and didn't let myself fall behind, even though there was no monitoring of my progress (as by professor in classroom).

I really liked the flexibility that the Learning Space offered. I would never let myself get too far behind, then if I knew I was going to have other things coming up in other courses, I had the option of working a little ahead of schedule. I really liked the flexibility.

"Even though I didn't get to know the other students very well, I didn't really care. The way the course was offered worked well for me in terms of my schedule time constraints and learning style."

However, other student comments focused on the dangers of poor time management and study skills:

"I didn't feel that I learned as much since I could easily procrastinate."

"Because I could do it on my own time I put it off and procrastinated. But when I did learn it I was motivated because it is interesting and fun material."

"Without going to class my motivation completely decreased. Because we didn't meet on a regular basis the class kind of slipped out of my thoughts."

"Since I had to learn everything on my own I often found myself putting the class off in favor of other classes."

"There was not enough structure for me."

"It was a good experience, however this method of learning does not fit my personality. (I'm a procrastinator.)"

"For me there was too much freedom and my grade reflected on that. I think I would of done better in a regular class."

\section{CONCLUSIONS}

From these comments and the preceding analysis it is apparent students' learning and study styles played a crucial role in their success in this course; perhaps even a bigger role than their learning styles play in the traditional classroom. If these connections hold true in further research, greater attention will need to be focused on individual student learning styles before an asynchronous learning course commences. Departments and schools that have made a significant commitment to distance learning may find it beneficial to provide students with a test of their learning styles upon admittance to the program. In that way, knowing their own strengths and weaknesses, students could better decide for themselves if an ALN would be a good experience. However, it is also probable through time, students--intuitively knowing their own tendencies--would self select themselves in or out of such courses.

High drop-out rates are a common problem with on-line courses. Carr's study [9] identified two study skills areas that may influence drop-out rates in on-line courses: attitude and the ability to identify main ideas. Students who do not fully appreciate the process of obtaining a degree in higher education may be at an increased risk of not completing the coursework in this learning environment. Likewise, students unable on their own to effectively ferret out the most important course information may not survive the ALN experience. 
While this project was one of the first to link learning study styles to asynchronous learning, further research will add more understanding. If this course's experience proves valid on a larger scale, time management and study aids skills will need to be emphasized before an ALN class begins. Students will need to understand the importance of skills, and will need to honestly evaluate their own abilities in those areas. Instructors will need to emphasize the importance of study skills at the outset, and will need to closely monitor throughout the semester the progress of each student. If a student is late with, or does a poor job on, an assignment the instructor will need to immediately initiate communication with the student to determine if poor study skills is the culprit.

More research with conceptual models such as the LASSI is needed to validate all these findings and to gain greater insights into the role of learning and study styles in an asynchronous environment. It will also be meaningful to investigate relationships with other types of learning models, such as the Price, Dunn and Dunn [10] model which measures environmental variables (noise, light, temperature) along with other emotional, sociological, physical, and psychological stimuli. The traditional classroom environment is usually controlled; temperature, lighting, noise, and other stimuli are the same for each student. Of course, in virtual classrooms external learning environments widely vary. The Price, Dunn and Dunn measures may help in identifying external environments and preferences that are conducive to success away from the traditional classroom conditions.

One improvement that will be made in this Research Methods section is the course grading scale will be expanded. More points will be added through the addition of regular weekly assignments. In this way, students will be required to access the course more often and will be less likely to "let the course slide." This extra work was actually requested by two students' written comments: "Overall I enjoyed this class, but I think next time to improve there could be more lectures/assignments to motivate students to learn the material." "Put assignments corresponding with each lecture to motivate students to listen to each one and to stay on top of their work." So, where traditionally this course had two exams and several major projects and/or assignments, numerous small scale assignments will be added to keep students "tuning in."

The instructor will also continue to work on improving the appearance of the web page through more simplified directions and instructions, and through more interesting PowerPoint applications. These changes might help students who are not accustomed to profitably using study aids.

The growing use of personal computers in education provides many new opportunities. However, as we move forward in the adoption of this new use of technology it will be beneficial to remember that people learn in a multitude of ways. Identifying the intersections between these different learning and study styles, and the processes of learning in an asynchronous environment will help to make the transition easier.

\section{REFERENCES}

1. Arvan, L., Ory, J.C., Bullock, C.D., Burnaska, K.K., and Hanson, M., The SCALE Efficiency Projects, Journal of Asynchronous Learning Networks, 2 (2), 1998.

2. Bond, N.W., A Multimedia Program in Associative Learning, Teaching of Psychology, 25 (4), 300302, 1998. 
3. Schutte, J.G., Virtual Teaching in Higher Education: The New Intellectual Superhighway or Just Another Traffic Jam?, California State University, Northridge, 1996. www.csun.edu/sociology/virexp.htm.

4. Sherman, R.C., Using the World Wide Web to Teach Everyday Applications of Social Psychology, Teaching of Psychology, 25(3), 212-216, 1998.

5. Wegner, S.B., Holloway, K.C., and Garton, E.M., The Effects of Internet-based Instruction on Student Learning, Journal of Asynchronous Learning Networks, 3 (2), 1999.

6. Hiltz, S.R., Impacts of College-Level Courses Via Asynchronous Learning Networks: Some Preliminary Results, Journal of Asynchronous Learning Networks, 2, 1997.

7. Ory, J.C., Bullock, C.D., and Burnaska, K.K., Gender Similarity in the Use of and Attitudes About ALN in a University Setting, Journal of Asynchronous Learning Networks, 1 (1), 1997.

8. Weinstein, C.E., LASSI User's Manual, Clearwater, Florida, H and H Publishing Company, Inc., 1987.

9. Carr, S., As Distance Education Comes of Age, The Challenge is in Keeping the Students, The Chronicle of Higher Education, Feb. 7, 2000.

10. Price, G.E., Dunn, R., and Dunn, K., PEPS (Productivity Environmental Preference Survey) Manual, Rev. ed., Lawrence, Kansas Price Systems, 1982. 